\title{
THE EFFECT OF PRINCIPALS' COMPETENCIES ON ACCREDITATION IN MADRASAH TSANAWIYAH THROUGHOUT TELLU SIATTINGE DISTRICT BONE REGENCY
}

\author{
Siti Aisyah', Muljono Damopolii², Sitti Mania3 \\ 1,2,3UIN Alauddin Makassar \\ 1,2,3Jalan H. M. Yasin Limpo No. 36 Samata-Gowa \\ Email: sitiaisyah110385@gmail.com¹, muljono.damopolii@uin-alauddin.ac.id², \\ sitti.mania@uin-alauddin.ac.id ${ }^{3}$
}

\begin{abstract}
:
This study described the effect of principals' competencies on madrasah/school accreditation in Madrasah Tsanawiyah in Tellu Siattinge District in Bone Regency. Substitution of principals frequently occurred, having an impact on the achievement of accreditation. The principals' competencies were managing and supervisory. Madrasah accreditation was the process of content standards, competency standards for graduates, standards for educators and educational staff, standards for facilities and infrastructure, financing standards, management standards, and procurement standards. Ex-post facto research was used to find the cause of an event. The population was 88 teachers, as well as the sample. The instrument was a questionnaire that was analyzed using descriptive statistics and inferential statistics by testing the hypothesis with the product-moment test and simple regression analysis. The results showed that the reality of principals competencies with 86.56 of the average response rate was in the very good category with $66.9 \%$. In the reality of madrasah accreditation, the average of respondents' responses was 87.57, which was in the very good category with $68.2 \%$. Furthermore, there was a positive and significant effect of principals' competencies on accreditation in Madrasah Tsanawiyah throughout Tellu Siattinge District in Bone Regency. The principals' competencies of madrasah, which was utilized well by their leadership, provided an increase in madrasah accreditation. It was evidenced by 0.832 of the coefficient and 0.000 of the significance.
\end{abstract}

\begin{abstract}
Abstrak:
Penelitian ini mendeskripsikan pengaruh kompetensi kepala madrasah terhadap akreditasi madrasah di Madrasah Tsanawiyah se-Kecamatan Tellu Siattinge Kabupaten Bone. Pergantian kepala madrasah sering terjadi, memberikan dampak terhadap pencapaian akreditasi madrasah. Kompetensi kepala madrasah di antaranya kompetensi manajerial dan kompetensi supervisi, sedangkan akreditasi madrasah dinilai melalui standar isi, standar proses, standar kompetensi lulusan, standar pendidik dan tenaga kependidikan, standar sarana dan prasarana, standar pembiayaan, standar pengelolaan serta standar penilaian. Penelitian ex-post facto digunakan dalam menemukan penyebab dari suatu peristiwa. Populasi penelitian adalah 88 guru sekaligus sebagai sampel. Teknik pengumpulan data dengan angket serta dianalisis dengan statistik deksriptif dan statistik inferensial dengan pengujian hipotesis dengan uji korelasi product moment dan analisis regresi sederhana. Hasil penelitian menunjukkan bahwa Realitas kompetensi kepala madrasah dengan ratarata tanggapan sebesar 86,56 berada pada kategori sangat baik dengan persentase sebesar $66,9 \%$. Realitas akreditasi madrasah rata-rata tanggapan responden sebesar 87,57 berada pada kategori sangat baik dengan persentase sebesar 68,2\%. Selanjutnya terdapat pengaruh yang positif dan signifikan kompetensi kepala madrasah terhadap akreditasi madrasah di Madrasah Tsanawiyah se-Kecamatan
\end{abstract}


Tellu Siattinge Kabupaten Bone. Kompetensi kepala madrasah yang dimanfaatkan dengan baik oleh kepala madrasah dalam kepemimpinannya memberikan peningkatan terhadap pencapaian akreditasi madrasah, hal ini terbukti dengan koefisien 0,832 dan siginifikansi 0,000.

\section{Keywords: \\ Madrasah Principals' Competencies, Madrasah Accreditation.}

How to Cite: Aisyah, S., Damopolii, M., \& Mania, S. (2020). The Effect of Principals' Competencies on Accreditation in Madrasah Tsanawiyah Throughtout Tellu Siattinge District Bone Regency. Lentera Pendidikan : Jurnal Ilmu Tarbiyah dan Keguruan, 23(2), 233-246. https://doi.org/10.24252/lp.2020v23n2i4.

\section{INTRODUCTION}

Education in Islam occupies a very important position. Education can be pursued through formal, non-formal, and informal educational institutions. Madrasah as Islamic educational institutions as formal, useful for character learners in Indonesia (Musfah, 2018: 28). The essence of an educational institution as an organization for forming aspects of students' knowledge, attitudes, and skills. Some problems in educational institutions namely the unequal opportunity to get an education, the low link between education and the world of work, the low quality of education, the large number of equivalent educational institutions located nearby (Sukmawati, 2019: 67) and the lack of commitment from stakeholders (Sukmawati, 2019: 67; Dewi, Restina, \& Ali, 2020: 44).

The quality management paradigm starts from the term inspection, and quality control to quality assurance, improvement, and development, through a continuous quality improvement work procedure (Satori, 2016: 128). The term quality develops along with the times. The development of quality was pioneered by W. Edwards Deming, Joseph Juran, and Philip B. Crosby, who is known as the father of quality. Deming's concept states that quality problems stem from management errors and failures. Joseph Juran introduced the 85/15 law: 85\% of quality is influenced by internal institutional processes, and Strategic Quality Management (quality management strategy) improves quality management. Crosby put forward another concept about quality. It is free, and failures and mistakes can be removed with a strong desire from the institution (Teaching Administration for Education, 2015:293). Efforts to improve education quality require professional and reliable human resources with their respective scientific competencies in preparing to compete in the future (Tilaar, 2001: 179). Communication regarding the need for organizational resources to support madrasah accreditation (Astenia, 2019: 1). Professional human resources at work can achieve progress in the quality of the madrasah organization.

Deming reveals that quality is full customer satisfaction. Parents are customers in education, parents' satisfaction means good management and vice versa, but managers must understand why parents are satisfied and why parents/customers choose the educational institution (Rohani, 2017: 45). Quality in education is called high quality/top 
quality to students; one of the measuring tools for the quality of madrasah is the accreditation of educational units' eligibility (Kemendikbud, 2018:3).

The accreditation approach, the outcome assessment approach, and the open system approach are used to ensure educational institutions' quality (Musfah, 2018: 106). School/madrasah accreditation is a comprehensive assessment process of an educational unit or program's appropriateness, carried out by an independent and professional institution in the form of a certification assessment.

Accreditation is carried out in determining the feasibility of educational programs as a form of public accountability. It is implemented openly, as stated in Law Number 20 of the 2003 year concerning the National Education System Chapter XVI Part Two of Article 60. Madrasah accreditation assessments are carried out regularly (Mulyono, 2015: 176), through 8 SNPs, namely content, process, graduate competency, teacher and educational staff, facilities and infrastructure, financing, management, and assessment standards.

According to Musfah (2018: 321), an educational institution's quality is caused by coordination, communication, human resource competence, both madrasah principals, teachers, and students, to their leadership. Stanley and Geofrey state that it is necessary to maximize stakeholders' values in achieving goals. It explains that the madrasah principals' efforts to achieve educational goals must involve all madrasah stakeholders.

The competence of the madrasah principal greatly determines the quality or accreditation of a madrasah. Competence is seen from a person's ability to produce a level of job satisfaction (Kompri, 2017: 3). The head of the madrasahs' competencies greatly determines the achievement of the institution's goals (Maulana, 2019: 55). According to Permendiknas No. 28/2010 quoted by Kompri, personality, organizational, entrepreneurial, supervisory, and social competencies are competencies that a madrasah head must have and being his main task as a teacher (Kompri, 2017: 5). The head of the madrasahs' competencies is known and used to guide developing duties and responsibilities. Related to competence, as Allah swt said in QS Al-Ruum: 30 as follow:

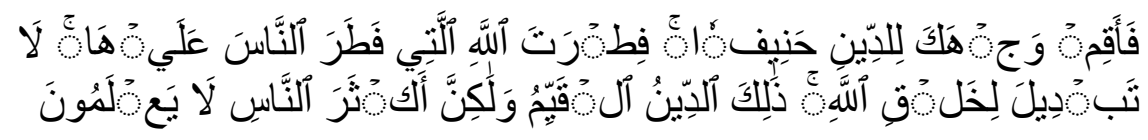

Translation:

So turn your faces straight to the religion of Allah; (stay on) the nature of Allah who created man according to that nature. there is no change in the fitrah of Allah. (That is) the straight religion; but most humans do not know.

Madrasah has potential human resources, especially madrasahs' principals. Therefore, it takes an effort to increase the competence that is owned by using it to advance madrasah.

Sakinah, Asy'ari, \& Ali (2019: 103) stated that the head on madrasahs' strategy could improve education quality. Fauzi \& Arnudin (2017: 239) suggest that the madrasah principal encourages, guides, and motivates all stakeholders in madrasah to work 
together to achieve the madrasah's vision, mission, and goals. Furthermore, Mahmud (2019: 218) measures the effectiveness of madrasahs through curriculum implementation, strategies, the effectiveness of the teaching and learning process, and the relationship between madrasah citizens, which always produces reliable output. Riyanto (2019: 180) finds an influence between the principal's managerial competence on student achievement as part of supporting the achievement of educational quality. The achievement of an educational institution's quality results from the manager's hard work in optimizing its competence (Sholihah, 2017: 68).

Nurkholis (2017: 88) found that madrasah's quality is influenced by the professionalism, namely academic qualifications and certificate ownership. Furthermore, Rosmaniar (2016: 159) found that instructional leadership and organizing learning that is implemented as a whole can improve the quality of madrasah, especially the quality of graduates or madrasah output. Competency standards of graduates boil down to assessing madrasah's quality (Maesaroh, 2018: 30). The madrasah principal's leadership can improve madrasah citizens' performance collaborating to improve quality (Nurani \& Sarino, 2017: 66). Simanullang (2016: 108) found that the principal can plan, implement, and evaluate school programs. It explains that the low compliance with national education standards has a direct bearing on madrasah accreditation.

Based on preliminary observations made in several Madrasah Tsanawiyah in Tellu Siattinge District, Bone Regency, it was found that the ability of madrasahs to fulfill national education standards did not meet standards. There still one madrasah had $\mathrm{C}$ category and MTs registered with the Ministry of Religion had B category, they were; Madrasah Tsanawiyah As'adiyah Pongka, Madrasah Tsanawiyah Nurul Aeyn As'adiyah Kampung Baru, Madrasah Tsanawiyah As'sadiyah Itterung, Madrasah Tsanawiyah Al Nur Patangnga, Madrasah Tsanawiyah Daarul Qur'an Pajalele, and Madrasah Tsanawiyah Nurul Ikhlas Al-Juhaefiyah.

There was also one madrasah that was no longer operational, namely MTs Istikhomah, which was located in Wanuae, Lea Village, Tellu Siattinge District. Due to the inability of the school to get accreditation and maintain its existence in the community, the number of students who enroll every year was reduced and had fewer teachers. Therefore, the remaining number of students was transferred to a madrasah closer to the location, namely MTs Panyiwi, which was located in Panyiwi Village, Cenrana District. Several facilities and infrastructure were still standing strong in the madrasah, but no teaching and learning process has been carried out, and the madrasah's location has been closed. Based on this explanation, madrasah accreditation was an important thing so that other madrasahs were able to maintain their existence in the community.

\section{RESEARCH METHOD}

This type of research is ex-post facto. This research was conducted to observe changes in behavior, symptoms, phenomena, or events as causes to be found (Sukardi, 2003: 16). Data Collection through a questionnaire which was arranged based on the research instrument as follows: 
Table 1. Research Instruments

\begin{tabular}{|c|c|}
\hline Variables & Indicator \\
\hline Principal $\quad$ Madrasahs' & Managerial Competence \\
\hline Competencies & Supervision Competence \\
\hline Accreditation of Madrasah & Content Standards \\
\hline & Process Standards \\
\hline & Graduate competence standard \\
\hline & Educators and Education Personnel \\
\hline & Standards \\
\hline & Facilities and Infrastructure Standards \\
\hline & Financing Standard \\
\hline & Management Standards \\
\hline & Assessment Standards \\
\hline
\end{tabular}

The population was 88 teachers in Madrasah Tsanawiyah throughout Tellu Siattinge District, Bone Regency, consisting of 34 males and 54 females. According to Arikunto (2010: 134), this research was a population study because the population in the research subject is less than 100 . Data were analyzed by simple regression analysis with the help of the SPPS version 2.1 program.

Before the instrument was distributed to the research location, it had been tested by expert judgment. The trials are then carried out at madrasahs with the same characteristics as the research location, namely Madrasah Tsanawiyah Lattekko, Awangpone District, with 15 respondents and 20 items. Questions for each variable found the respective results as follows:

Table 2. Results of Testing the Validity of the Madrasah Principals' Competence Instruments

\begin{tabular}{cccl}
\hline \multirow{2}{*}{$\begin{array}{c}\text { Statement } \\
\text { Items }\end{array}$} & \multicolumn{3}{c}{ Validity } \\
\cline { 2 - 4 } & $\begin{array}{c}\text { Pearson } \\
\text { Correlation }\end{array}$ & r Tabel & Conclusion \\
\hline 1 & 0.58 & 0.30 & Valid \\
\hline 2 & 0.58 & 0.30 & Valid \\
\hline 3 & 0.67 & 0.30 & Valid \\
\hline 4 & 0.35 & 0.30 & Valid \\
\hline 5 & 0.57 & 0.30 & Valid \\
\hline 6 & 0.60 & 0.30 & Valid \\
\hline 7 & 0.70 & 0.30 & Valid \\
\hline 8 & 0.49 & 0.30 & Valid \\
\hline 9 & 0.56 & 0.30 & Valid \\
\hline 10 & 0.62 & 0.30 & Valid \\
\hline 11 & 0.60 & 0.30 & Valid \\
\hline
\end{tabular}




\begin{tabular}{llll}
\hline 12 & 0.47 & 0.30 & Valid \\
\hline 13 & 0.57 & 0.30 & Valid \\
\hline 14 & 0.58 & 0.30 & Valid \\
\hline 15 & 0.60 & 0.30 & Valid \\
\hline 16 & 0.40 & 0.30 & Valid \\
\hline 17 & 0.57 & 0.30 & Valid \\
\hline 18 & 0.46 & 0.30 & Valid \\
\hline 19 & 0.43 & 0.30 & Valid \\
\hline 20 & 0.57 & 0.30 & Valid \\
\hline
\end{tabular}

Based on the trial of the madrasah principal competence instruments. All statement items distributed to 15 respondents could be categorized as valid because the overall value of the Pearson correlation met the requirements proposed; that was $\geq 0.30$.

Table 3. Results of Testing the Validity of Madrasah Accreditation Instruments

\begin{tabular}{cccl} 
Statement $\begin{array}{c}\text { Validity } \\
\text { Items }\end{array}$ & $\begin{array}{c}\text { Pearson } \\
\text { Correlation }\end{array}$ & r Table & Conclusion \\
\hline 1 & 0.35 & 0.30 & Valid \\
\hline 2 & 0.69 & 0.30 & Valid \\
\hline 3 & 0.61 & 0.30 & Valid \\
\hline 4 & 0.56 & 0.30 & Valid \\
\hline 5 & 0.54 & 0.30 & Valid \\
\hline 6 & 0.63 & 0.30 & Valid \\
\hline 7 & 0.54 & 0.30 & Valid \\
\hline 8 & 0.50 & 0.30 & Valid \\
\hline 9 & 0.49 & 0.30 & Valid \\
\hline 10 & 0.60 & 0.30 & Valid \\
\hline 11 & 0.41 & 0.30 & Valid \\
\hline 12 & 0.35 & 0.30 & Valid \\
\hline 13 & 0.67 & 0.30 & Valid \\
\hline 14 & 0.85 & 0.30 & Valid \\
\hline 15 & 0.32 & 0.30 & Valid \\
\hline 16 & 0.76 & 0.30 & Valid \\
\hline 17 & 0.54 & 0.30 & Valid \\
\hline 18 & 0.80 & 0.30 & Valid \\
\hline 19 & 0.35 & 0.30 & Valid \\
\hline 20 & 0.39 & 0.30 & Valid \\
\hline
\end{tabular}

Based on the output above, the 20 statement items with 15 respondents could be categorized as valid because the overall value of the Pearson correlation met the requirements proposed; that was $\geq 0.30$. 
Furthermore, the reliability test of the instruments used was carried out with the following results:

Table 4. Reliability Test for Madrasah Principals' Competence Instruments

Cronbach's Alpha N of Items

$.864 \quad 20$

Table 5. Reliability Test of Madrasah Accreditation Instruments

Cronbach's Alpha $\mathbf{N}$ of Items

$.857 \quad 20$

Based on the output table of SPSS version 21, there were $\mathrm{N}$ of Items, which meant the number of questionnaire statements was 20 items with a Cronbach's Alpha value was 0.864 of the madrasah principals competencies and 0.787 of the madrasah accreditation. Each of them was greater than 0.60. Reliability was the basic requirement for the instrument. Then, it could be said that the madrasah accreditation instrument was reliable or consistent.

\section{RESULTS AND DISCUSSION}

\section{The Reality of Madrasah Principals' Competencies in Madrasah Tsanawiyah throughout Tellu Siattinge District Bone Regency}

The reality of the madrasah principals' competencies indicated a good ability applied by the head of the madrasah in his/her leadership. As in the Regulation of the Minister of National Education No. 28 of 2010 concerning madrasah principals' competencies, namely personality, managerial, entrepreneurial, supervisory, and social competencies. Competence was the knowledge, understanding, abilities, and characteristics of the principal of the madrasah. The principal of a madrasah devoted himself/herself to an educational institution developing tasks to advance the educational institution he/she led. Nurkholis (2017) explained that academic qualifications and ownership of certificates by the principal were proof of professionalism. Therefore, the principal who could influence employees was a leader who starts from himself. Managing an organization that had innovation constantly supervised and had a social spirit was an ideal leader.

Tabel 6. Interpretation category of madrasah principals competence

\begin{tabular}{cccc}
\hline Interval & Category & Frequency & Persentase \\
\hline $20-36$ & Very Bad & 0 & $0 \%$ \\
\hline $37-52$ & Not Good & 0 & $0 \%$ \\
\hline $53-68$ & Fairly Good & 0 & $0 \%$ \\
\hline $69-84$ & Good & 30 & $34.1 \%$ \\
\hline
\end{tabular}




\begin{tabular}{cccc}
\hline $85-100$ & Very Good & 58 & $66.9 \%$ \\
\hline Total & & 88 & $100 \%$ \\
\hline
\end{tabular}

The reality indicated that there was good ability applied by the head of the madrasah in his/her leadership. As in the Regulation of the Minister of National Education No. 28 of the 2010 Year concerning madrasah principals' competencies, namely personality, managerial, entrepreneurial, supervisory, and social competencies. However, the measurement of managerial competence and supervision of madrasah principals was carried out.

Competence was the knowledge, understanding, abilities, and characteristics of madrasahs' principal. The head of the madrasah, who devoted himself/herself to an educational institution, developed tasks in advancing the educational institution he/she led. Technical, human relations, and conceptual skills as managerial skills in implementing a madrasah principal's duties Sulistyorini (2009: 180). As the principal manager of the madrasah in the highest position in educational institutions. To spearhead the success of the organization (Rohiat, 2012: 33). Managerial competence was the ability of the head of a madrasah in carrying out management functions, namely planning, organizing, implementing, and supervising activities in madrasah.

In carrying out his/her duties as a supervisor, the principal must master and carry out his duties properly. The madrasah principal was responsible for all school activities, managing the teaching and learning process, and managing all matters relating to students' personnel, facilities, infrastructure, and administration. finance and regulates had relationships with the community (Tatang, 2016: 91). According to Simanullang (2016: 108), there were the main competencies that madrasah principals must possess. This competency was carried out in the evaluation of madrasah programs. Nurkholis (2017) explained that academic qualifications and ownership of certificates by the principal are proof of professionalism. Therefore, the principal who could influence employees was a leader who started from himself/herself. The ability to manage the organization, innovate, supervise, and have a social spirit was an ideal leader.

\section{The Reality of Madrasah Accreditation in Madrasah Tsanawiyah in Tellu Siattinge District Bone Regency}

After conducting a descriptive analysis, it was known that from 88 teachers in Madrasah Tsanawiyah, the minimum result was 70 and the maximum value was 98 . The total number of all respondents' answers was 7.706. The standard deviation was 8.170, with 87.57 of average respondent responses, which was in the interval 85-100 with $68.2 \%$ in the very good category. The following table explained this:

Tabel 7. Interpretation Category of Madrasah Accreditation

\begin{tabular}{cccc}
\hline Interval & Category & Frequency & Persentase \\
\hline $20-36$ & Very Bad & 0 & $0 \%$ \\
\hline $37-52$ & Not Good & 0 & $0 \%$ \\
\hline $53-68$ & Fairly Good & 0 & $0 \%$ \\
\hline $69-84$ & Good & 28 & $31.8 \%$ \\
\hline
\end{tabular}




\begin{tabular}{cccc}
\hline $85-100$ & Very Good & 60 & $68.2 \%$ \\
\hline Total & & $\mathbf{8 8}$ & $\mathbf{1 0 0 \%}$ \\
\hline
\end{tabular}

The accreditation process was systematically carried out to assist and empower educational programs and units to develop their resources to achieve national education goals. Comprehensive accreditation instruments would be developed based on standards that refer to the National Education Standards. It was based on government regulation No. 19 of the 2005 Year, which established the education component's minimum criteria. As stated in article 1 of paragraph 1, the National Education Standards were the minimum criteria for the educational system in all jurisdictions of the Republic of Indonesia. The National Education Standards must be used as quality standards to determine schools' quality or madrasahs (Rukiyah, 2016: 48). This accreditation was used as an assessment tool for educational institutions regarding the quality and the quantity of a particular school/madrasah.

Madrasah accreditation, according to the results mentioned earlier, indicated that madrasah accreditation for educational institutions located in Tellu Siattinge Subdistrict in Bone Regency was an excellent accreditation. The accreditation assessment could be seen from the acquisition of accreditation from BANS/M with B and one madrasah with C category. Some of the madrasahs in the region were located in a slightly remote area but could get accreditation achievements quickly. Madrasah accreditation assessment was measured based on the minimum criteria. National education standards were the minimum criteria for the educational system following PP RI No. 19 of 2007 concerning Education Management Standards by Primary and Secondary Education Units consisting of content standards, process standards, competency of graduates, educators, and education personnel standards, facilities and infrastructure standards, management, financing, and educational assessment.

\section{The Effect of Madrasah Principals' Competence on Madrasah Accreditation in Madrasah Tsanawiyah throughout Tellu Siattinge District Bone Regency}

1. Product-Moment Correlation of Madrasah Principals and Madrasah Accreditation

The correlation between madrasah principals' competencies and madrasah accreditation in Madrasah Tsanawiyah throughout Tellu Siattinge District in Bone Regency in the Pearson correlation was 0.784 . There was a positive correlation by forming a straight line, thus indicating that the high and low scores of madrasah principals' competencies were followed by the high and low scores of madrasah accreditation. The correlation value was in the interval of 0.60-0.799, which indicated a strong relationship level because there was a straight line connecting madrasah principals' competencies and madrasah accreditation variables.

Table 8. Correlation of Madrasah Principalss' Competencies and Madrasah Accreditation

\begin{tabular}{|c|c|c|c|}
\hline & & $\begin{array}{l}\text { Madrasah } \\
\text { Principals } \\
\text { Competence }\end{array}$ & $\begin{array}{l}\text { Madrasah } \\
\text { accreditation }\end{array}$ \\
\hline $\begin{array}{l}\text { Madrasah } \\
\text { Principals }\end{array}$ & $\begin{array}{l}\text { Pearson } \\
\text { Correlation }\end{array}$ & 1 & $.784^{* *}$ \\
\hline
\end{tabular}




\begin{tabular}{|c|c|c|c|}
\hline \multirow[t]{2}{*}{ Competence } & Sig. (2-tailed) & & .000 \\
\hline & $\mathrm{N}$ & 88 & 88 \\
\hline \multirow{4}{*}{$\begin{array}{l}\text { Madrasah } \\
\text { accreditation }\end{array}$} & Pearson & $.784^{* *}$ & 1 \\
\hline & Correlation & & \\
\hline & Sig. (2-tailed) & .000 & \\
\hline & $\mathrm{N}$ & 88 & 88 \\
\hline
\end{tabular}

Madrasah principals' competencies had a positive and significant correlation with madrasah accreditation in Madrasah Tsanawiyah throughout Tellu Siattinge District in Bone Regency. The following was the line of correlation between madrasah principals' competencies and madrasah accreditation. It look like the following graph:

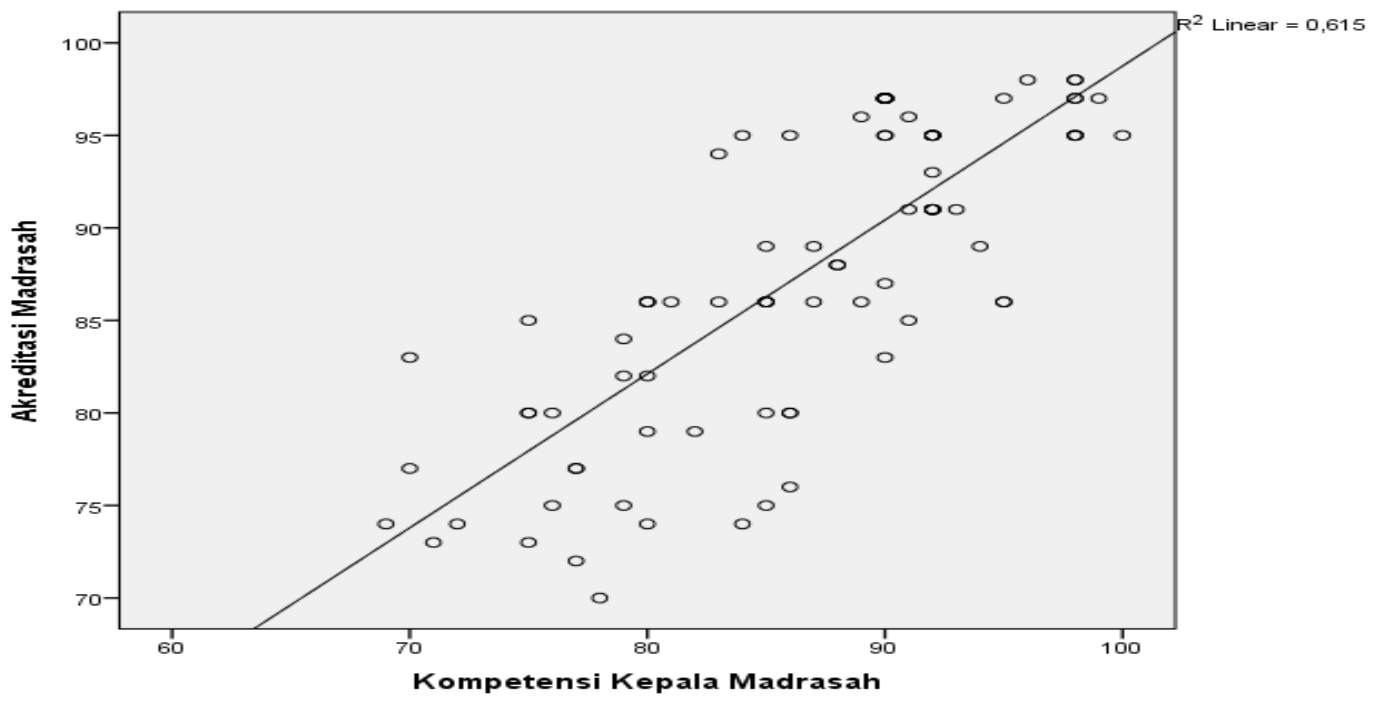

Figure 1. Scatter Chart of Madrasah Principals' Competencies and Madrasah's Accreditation

The influence of madrasah principals' competencies and madrasah accreditation could be seen from the following table:

Table 9. Linear Regression of Madrasah Principals Competence on Madrasah Accreditation

\begin{tabular}{llllll}
\hline \multicolumn{1}{c}{ Model } & \multicolumn{2}{l}{$\begin{array}{l}\text { Unstandardized } \\
\text { Coefficients }\end{array}$} & $\begin{array}{l}\text { Standardized } \\
\text { Coefficients }\end{array}$ & t & Sig. \\
\cline { 2 - 5 } & B & $\begin{array}{l}\text { Std. } \\
\text { Error }\end{array}$ & Beta & \\
\hline (Constant) & 15.554 & 6.171 & & 2.520 & .014 \\
\hline $\begin{array}{l}\text { Madrasah } \\
\text { Principals' } \\
\text { Competencies }\end{array}$ & .832 & .071 & .784 & 11.714 & .000 \\
\hline & & & & \\
\hline
\end{tabular}


Based on the description of the table, the sig. number obtained was 0.000 . As a guide in determining the effect as if the value was sig. smaller than 0.05 . It was known that there was an influence of the principals' competencies on madrasah accreditation with a second significance value of $n 95 \%$. The regression equation for this variable was $Y=15.554+0.832 \mathrm{X}$. The increase in each $\mathrm{Y}$ value was 0.832 , indicating an effect of principals' competencies on madrasah accreditation. Therefore, these results added to the understanding and strengthen the findings of previous experts that the madrasah principals' competencies were a prerequisite for being an ideal school principal and madrasah principals' competencies as the ability of madrasah principals in improving the quality of madrasah through madrasah accreditation assessments.

One indicator of national education quality was madrasah's quality, which was managed professionally by the principal of madrasah with democratic leadership. He/she had understanding, abilities, accommodation, and met the employees and their needs. The factor of the principals' role was one of the successes in achieving the goals of the madrasah. The head of madrasah used all his potential and potential organizational resources to accomplish the madrasah's goals.

Madrasah quality control was carried out by increasing teacher competence, accreditation, and national exam scores (Basuni, 2013: 427). Furthermore, Basuni (2017: 1) explained that teacher performance had a relationship with madrasah accreditation levels (A, B, C, and D scales). In educational institutions' management adhered to those listed in the eight standards in the BSNP (National Education Standards Agency) regarding National Education Standards, namely content, process, graduation, teacher, education staff, facilities, infrastructure, management, financing, and assessment standards (Rohani, 2017: 24). The eight standards were used as an assessment for the accreditation of a madrasah.

Madrasah principal in a dynamic environment required attention to internal and external needs. Madrasahs Public and private had received supervision and assessment from various parties and stakeholders, both by the government and National Accreditation Board School/Madrasah (BAN S/M). The relation among the head of the madrasah, supervisors, teachers, and students' parents in the organizational structure must always be established through a communication process. The communication process still occurred and even continued to evolve, requiring the head of the madrasah to respond to various problems and madrasah needs that could not be predicted. Principal madrasahs' abilities in establishing cooperation communication and others with subordinates and the environment were needed. The social madrasah principals' competencies were the important part that must be possessed in his/her leadership in an educational institution, namely the madrasah.

The systematic principle in the implementation of accreditation was carried out to encourage the empowerment of education units to optimize their resources in achieving goals. All instrument accreditation was used in the development, according to the National Education Standards. Based on government regulation Number 19 of the 2005 Year concerning the minimum criteria for education component, article 1 of paragraph 1 
stated that the National Education Standards were the minimum criteria for the education system in all jurisdictions of the Republic of Indonesia (Rukiyah, 2016: 48). This accreditation was used as an educational assessment tool regarding the quality and the quantity of a particular madrasah.

Educational institutions' management adhered to those listed in the eight standards in National Education Standards Agency (BSNP) regarding National Education Standards including content, process, graduation, educators, educational staff, facilities, infrastructure, management, financing, and assessment standards (Rohani, 2017: 24). The achievement of 8 SNP aspects affected the success of accreditation . So, the madrasah work plan was an effort to meet and/or exceed the eight standards.

This research was in line with Colodarci, Arthur, \& Getzels (2012: 3) research that the principals' ability (competence) would affect the effectiveness and efficiency of madrasah quality. Advanced and quality educational institutions could create quality education, starting from increasing madrasah accreditation. Also, Nurkholis (2017) found that the principal of madrasahs' professionalism influenced quality. The competence of madrasah principals was also explained by Rosmaniar (2016) that instructional leadership could improve madrasahs' quality. The head of the madrasah was the leader of an agency/institution in influencing his/her subordinates by giving instructions, motivation, bonuses, and others, with the head of the madrasahs' leadership competency. It could affect members of the organization in carrying out their authority and responsibilities called tupoksi so that the quality of the madrasah could be improved.

\section{CONCLUSION}

The reality of the principals' competencies in Madrasah Tsanawiyah throughout Tellu Siattinge District in Bone Regency with average responses from 88 respondents. The respondents' average response was 86.56 , with $66.9 \%$ in the very good category. The reality of madrasah accreditation in Madrasah Tsanawiyah throughout Tellu Siattinge District in Bone Regency, the average response of respondents, was 87.57 with $68.2 \%$ being in the very good category.There was a positive and significant influence on madrasah principals' competencies on madrasah accreditation in Madrasah Tsanawiyah in Tellu Siattinge District in Bone Regency with 0.832 of the coefficient and 0.000 of significance. It was known that the increase in the competence of the head of the madrasah would affect madrasah accreditation.

\section{REFERENCES}

Arikunto, S. (2010). Research Procedure : A Practice Approach. Jakarta: Rineka Cipta.

Astenia, D., Rugaiyah, \& Karniati, N. (2019). The Evaluation of the School/Madrasah Accreditation Implementation Program in Palembang City. Indonesian Journal of Education Review, $6(1)$. http://journal.unj.ac.id/unj/index.php/ijer/article/view/14075.

Basuni, F. (2011). Accreditation on Teacher's Performance and Madrasah National 
Examination. Jurnal Evaluasi Pendidikan, 2(1). https://doi.org/https://doi.org/10.21009/JEP.021.01.

Basuni, F. (2013). Membangun Pendidikan Madrasah yang Kompetitif di Era Globalisasi. Jurnal Analisis Studi Keislaman, 8(2). https://doi.org/https://doi.org/10.24042/ajsk.v13i2.704.

Colodarci, Arthur, P., \& Getzels, J. W. (2012). The Use of Theory in Educational Administration. California: Stanford University Press.

Dewi, Restina, P., \& Ali, N. (2020). Improving Madrasah Accreditation Scores through Quality Assurance Institutions. JMPI: Journal of Islamic Education Management, 5(1). file:///C:/Users/PC/Downloads/Documents/6200.pdf.

Fauzi, A., \& Arnudin. (2017). Leadership Role of Principal on Improving the Performance of Teacher at Madrasah Aliyah Darul Muqimin Pandeglang. Saudi Journal of Humanities and Social Science, 2(3). http://scholarsmepub.com/wpcontent/uploads/2017/04/SJHSS-23240-247.pdf.

Kompri. (2017). Standardization of Competency of Madrasah Principals: Theoretical Approach to Professional Practice (I). Jakarta: Kencana.

Maesaroh, S. (2018). Management of Competency Improvement of Graduates in Madrasah. Isema Journal, 3(1). https://doi.org/https://doi.org/10.15575/isema.v3i1.3280.

Mahmud, A. (2019). Principle of Madrasah Head Management in Realizing Effective Madrasah. International Conference of Moslem Society, 3. https://doi.org/https://doi.org/10.24090/icms.2019.2431.

Maulana, T. (2019). Leadership Strategies of Madrasah Heads to Improve Professional Competence of PAI Teachers (Research Studies at MA Baabussalam. Bandung City). Tahzibi Journal, https://doi.org/https://doi.org/10.24853/tahdzibi.4.1.55-66.

Mulyono. (2015). Madrasah Accreditation. Madrasah Journal, 11(2). https://doi.org/https://doi.org/10.18860/jt.v2i2.1821.

Musfah, J. (2018). Educational Management: Applications, Strategy, and Innovation (I). Jakarta: Prenada Media Group.

Nurani, R. T., \& Sarino, A. (2017). The Role of Principal Leadership and Work Motivation in Improving Vocational High School Teacher Performance (The Role of School Leadership and Work Motivation to Increase Teacher Performance at Vocational High School. Journal of Office Management Education, 2(1). https://doi.org/https://doi.org/10.17509/jpm.v2i1.14613.

Nurkholis. (2017). Educational Improvement towards Effective Madrasah. Advance in Social Science. Education and Humanities Research, 6(6). https://doi.org/https://doi.org/10.2991/yicemap-17.2017.15.

Riyanto. (2019). The Influence of Principal Managerial Competence and Teacher Motivation on Student Achievement of Public Elementary Schools in Pulau Rimau District. JMKSP Journal (Journal of Management, Leadership, and Education Supervision), 4(2). https://doi.org/http://dx.doi.org/10.31851/jmksp.v4i2.2907.

Rohani, S. (2017). Handbook: Quality-Based Management of Islamic Schools (I). Love Books Media.

Rohiat. (2012). School Management: Basic Theory and Practice (IV). Bandung: PT Refika Aditama. 
Rosmaniar, W. (2016). Headmaster of Instructional Leadership and Organizational Learning on the Quality of Madrasah and the Quality of Graduates the State Madrasah Aliyah at Jakarta Capital Region. Canadian Center of Science and Education, 6(1). https://eric.ed.gov/?id=EJ1099375.

Rukiyah, I. (2016). Improving the Quality of Education Services through Accreditation of Education Units. Ittihad: Journal of Kopertais Region XI Kalimantan, 14(25). file://C:/Users/PC/Downloads/863-2371-1-PB.pdf.

Sakinah, Asy'ari, \& Ali. (2019). The Strategy of Madrasah Headmaster in Improving the Quality of Islamic Education. International Journal of Contemporary Islamic Education, 1. https://doi.org/10.24239/ijcied.Vol1.Iss1.7.

Satori, D. (2016). Supervision and Quality Assurance of Education (II). Bandung: Alfabeta.

Sholihah. (2017). Considering the Quality of Islamic Education and the Managerial Competence of School Principals. Mukaddimah Journal: Journal of Islamic Studies, 2(1). file:///C:/Users/PC/Downloads/Documents/1358-2808-1-SM.pdf.

Simanullang, P. (2016). Performance Evaluation of Headmaster in Preparing the Work Plan of the School. Proceedings of the 1 St Annual International Seminar on Transformative Education and Educational Leadership (AISTEELL). http://aisteel.unimed.ac.id/proceeding-aisteel-2016/.

Sukardi. (2003). Educational Research Methodology (I). Jakarta: Earth Literacy.

Sukmawati, Ujang, Y., \& Soeharto. (2019). The Improvement of Accreditation through Evaluation on Management Standards in Madrasah Tsanawiyah. EST: Journal of Educational Science and Technology, 5(1). https://doi.org/https://doi.org/10.26858/est.v5i1.9260.

Sulistyorini. (2009). Islamic Education Management (I). Yogyakarta: Terrace.

Tatang. (2016). Education Supervision (I). Bandung: Pustaka Setia.

Tilaar, H. (2001). Several Agenda for National Education Reform in 21st Century Perspective. Magelang: Indonesia Teras. 